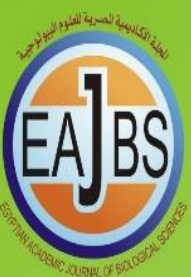

EGYPTIAN ACADEMIC JOURNAL OF BIOLOGICAL SCIENCES BOTANY
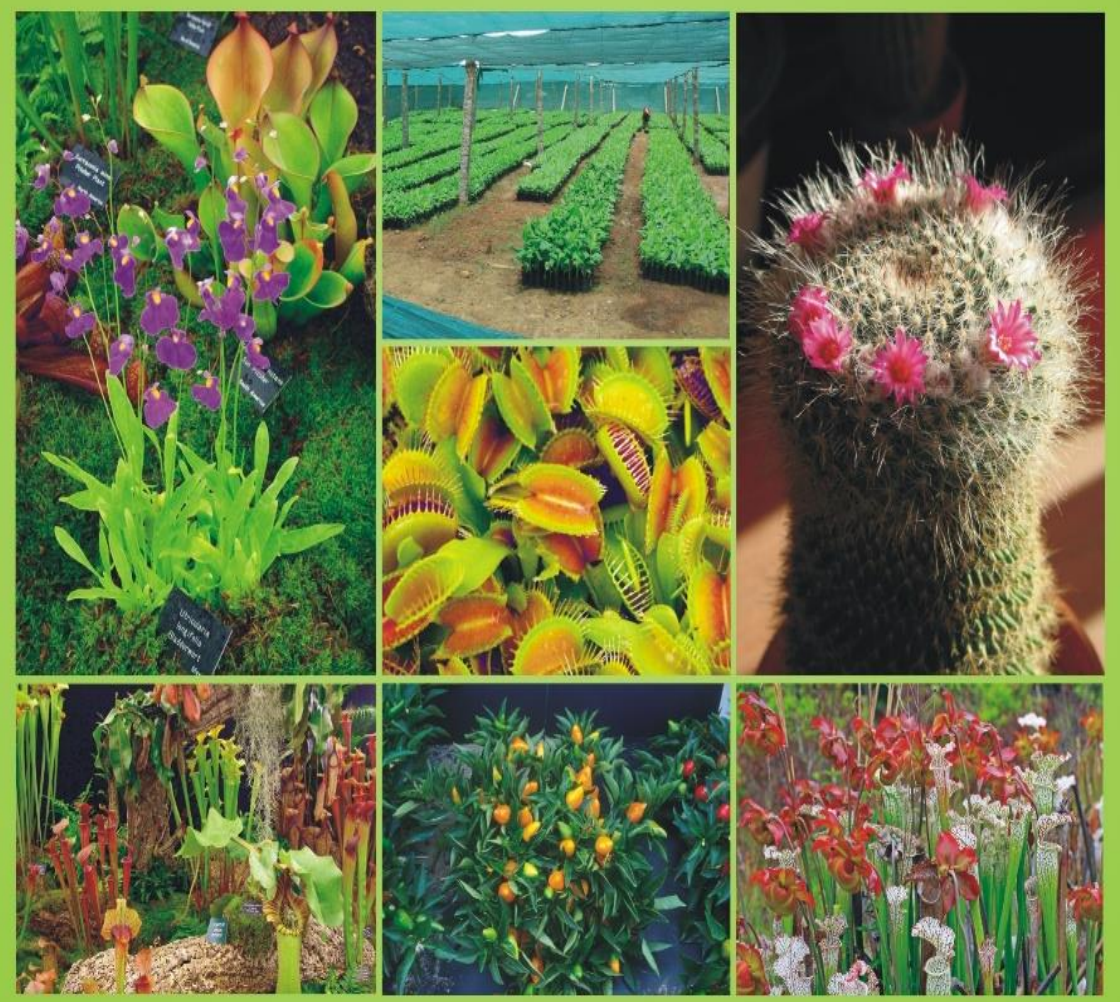

ISSN 2090-3812 
Egypt. Acad. J. Biolog. Sci., 12(2): 1-10 (2021)

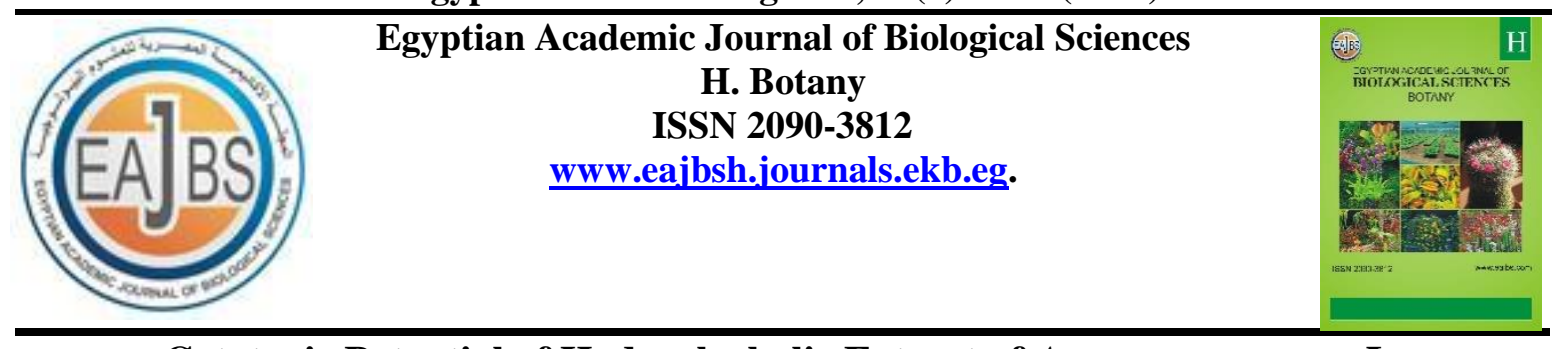

\title{
Cytotoxic Potential of Hydroalcoholic Extract of Annona squamosa L. Fermented Cotyledon
}

\author{
Christianah Adebimpe Dare* and Abdulqudus Olatunji Ayanwale \\ Department of Biochemistry, Osun State University, Osogbo, Nigeria. \\ *E-mail: bimpeoasis@yahoo.com
}

\section{ARTICLE INFO}

Article History

Received:27/6/2021

Accepted:31/7/2021

\section{Keywords:}

Cancer, tumour,

GC-MS, sugar

apple, toxicity

\section{ABSTRACT}

The present study was aimed to evaluate the cytotoxic potential of hydroalcoholic extract of Annona squamosa L. using Allium cepa test and Brine Shrimp Lethality assay. Fresh and ripe sugar apple fruits were collected from an orchard at Ota-Efun, Olorunda Local Government, Osogbo, Nigeria $\left(07^{\circ} 32^{\prime} 30.2496^{\prime \prime} \mathrm{N}, 04^{\circ} 31^{\prime} 41.7036^{\prime \prime} \mathrm{E}\right)$ and their identity authenticated at IFE Herbarium, Department of Botany, Obafemi Awolowo, University, IleIfe, Nigeria. The seeds were collected, fermented locally for 7days, and ovendried. The cotyledon was separated from the seed coat, pulverized, defatted, and exhaustively extracted with $80 \%$ ethanol. The extract was concentrated and air-dried and named Annona squamosa Fermented Cotyledon Hydroalcoholic Extract (AFCHE). The extract was screened for phytoconstituents on GC-MS machine. Allium cepa test and brine shrimp lethality bioassay were used to screen for the cytotoxic potential of AFCHE. The root length and protein concentration of the onion root after 7 days of exposure showed a significant decrease with an increase in AFCHE concentration and an increase in percentage growth inhibition of the root. The $\mathrm{LC}_{50}$ obtained from the brine shrimp lethality bioassay qualified AFCHE as a highly toxic substance and a good anticancer agent worth screening.

\section{INTRODUCTION}

Cancer is the second reason for death worldwide. Conventional therapies for cancer include surgery, cytotoxic chemotherapy, immunotherapy and radiation therapy which are used as single or combinatorial therapy have some side effects (Dutta et al., 2019). Today, many plant-derived compounds "phytochemicals" have been identified that have anti-tumour properties. For example, induction of apoptosis and inhibition of cell proliferation which finally decrease the risk of cancer make these components useful for cancer treatment (Sultana et al., 2021).

A simple search on Google Scholar on 21 June 2018 with the key "Allium test" produced 3170 hits, showing the wide use of the test in a variety of different investigations. A few examples are studies examining the effects of toxic plants (Pesnya et al., 2017), nanoparticles (Yekeen et al., 2017), synthetic plant hormones such as etephon (Yavuz and Kiliç, 2017), industrial waste (Dutta et al., 2018), aquatic environmental samples (Zotina et al., 2015), etc. The lethality of the test sample in a simple zoological organism like the brine shrimp (Artemia salina) has been utilised by many researchers and has proven to be a useful 
tool in screening various chemical compounds found in various bioactivities (Azad et al., 2019).

Cytotoxicity testing is preliminary research to the discovery of anti-cancer agents, and cancer is a major global health problem. The majority of anti-cancer drugs that enter clinical trials exhibit little or no therapeutic benefits and fail to obtain regulatory approval. Hence, this study seeks to provide information on cytotoxicity activities of hydroalcoholic extract of fermented cotyledon Annona squamosa to be evaluated for potential as an anticancer agent. The use of the Allium test (AT) to check the potential genotoxicity of several types of chemical, physical and biological agents has a long history in scientific literature, from the first investigation by Levan (1938) to the more standardized method proposed by Fiskesjö (1985) and later Rank (2003).

\section{MATERIALS AND METHODS}

\section{Materials:}

\section{Fruit Collection and Identification:}

Fresh and ripe sugar apple fruit was collected from an orchard at Ota- Efun. Olorunda Local Government, Osogbo, Osun State, Nigeria (07³2' 30.2496" N, 04 31' 41.7036"E). The Fruit was authenticated at IFE Herbarium, Department of Botany, Obafemi Awolowo University, Ile-Ife with number IFE-17805. Allium cepa bulbs were purchased from Oja Sanya, Ede, Osun State, Nigeria, and authenticated at IFE Herbarium, Department of Botany, Obafemi Awolowo University, Ile-Ife with number IFE-17944. Experiments were conducted in the Biochemistry laboratory of Osun state University, Osogbo.

\section{Reagents and Chemicals:}

All the reagents used in this study were of analytical grade and were procured from various sources.

\section{Methods:}

\section{Processing of Annona squamosa Seed:}

The Annona squamosa seed was fermented traditional by wrapping the seeds with the pulp on them in banana leaves and kept inside a dark cupboard for seven (7) days for fermentation (Dare et al., 2013). These seeds were shelled by separating the seed from the cotyledon and the cotyledon was milled separately into powder using QBL Grinder for easy extraction.

\section{Defatting Annona squamosa Seeds:}

Typically, $20 \mathrm{~g}$ of the cotyledon was extracted with $400 \mathrm{ml}$ diethyl ether, using a soxhlet extractor. This extracted the non-polar components (oil) from the samples. The extracted oil was kept for future use and the residue was dried and weighed.

\section{Preparation of Hydroalcoholic Extract of Annona squamosa:}

The defatted sample was exhaustively extracted with $80 \%$ ethanol. The hydroalcoholic extract was concentrated on a rotary evaporator and termed Annona squamosa fermented cotyledon hydroalcoholic extract (AFCHE). The extract was air-dried and kept in the freezer for further use.

\section{Gas Chromatography-Mass Spectrometry (GC-MS) Analysis of AFCHE:}

After extraction, gas chromatography-mass spectrometry (GC-MS) was employed in the analysis of the compounds present in AFCHE. This was done according to the procedure described by Akther et al. (2017), using a 7820A gas chromatograph coupled to 5975 inert mass spectrometer (with triple-axis detector) and electron impact source (Agilent Technologies). The separation of the compounds was carried out on HP-5 Capillary Column coated with $5 \%$ Phenylmethyl siloxane $(30 \mathrm{~m}$ length $\times 0.32 \mathrm{~mm}$ diameter $\times 0.25 \mu \mathrm{m}$ film thickness) (Agilent Technologies). The carrier gas was helium used at a constant flow rate 
of $1.573 \mathrm{ml} / \mathrm{min}$, an initial nominal pressure of $1.9514 \mathrm{psi}$ and at an average velocity of 46 $\mathrm{cm} / \mathrm{s}$. sample $(1 \mu \mathrm{l})$ was injected in split less mode at an injection temperature of $260{ }^{\circ} \mathrm{C}$. Purge flow was $1 \mathrm{ml} / \mathrm{min}$ at $0.50 \mathrm{~min}$ with a total gas flow rate of $23.355 \mathrm{ml} / \mathrm{min}$ and the gas saver mode was switched on. The oven was initially programmed at $60{ }^{\circ} \mathrm{C}$ for $1 \mathrm{~min}$, and then the temperature was gradually increased at the rate of $4{ }^{\circ} \mathrm{C} / \mathrm{min}$ to $110{ }^{\circ} \mathrm{C}$ for $3 \mathrm{~min}$. run time was $56.25 \mathrm{~min}$ with a $3 \mathrm{~min}$ solvent delay. The mass spectrometer was operated in electron-impact ionisation mode at $70 \mathrm{eV}$ with the ion source temperature of $230{ }^{\circ} \mathrm{C}$, quadrupole temperature of 150 mode at $70 \mathrm{eV}$ with an ion source temperature of $280{ }^{\circ} \mathrm{C}$. Scanning of possible compounds was from $\mathrm{m} / \mathrm{z} 30$ to $550 \mathrm{Da}$ at $2.62 \mathrm{~s} / \mathrm{scan}$ rate. The relative percentage amount of each component was calculated by comparing peak area to the total areas, and interpretation on the mass spectrum of GC-MS was done using the database of National Institute of Standard and Technology (NIST) having more than 62,000 patterns. The unknown compounds were identified by comparing measured mass spectral data with those in NIST14 Mass Spectral Library.

\section{Root Growth Inhibition Assay:}

The root growth inhibitory assay was carried out as reported (Sharma and Vig, 2012) using A. cepa. Typically, outer scales and root remnants of the onion bulbs (30) were carefully removed in order not to destroy the root primordia. The A. cepa bulbs were exposed for $96 \mathrm{~h}$ to varying concentrations $(0,100,200,300,400$ and $500 \mu \mathrm{g} / \mathrm{ml})$ of AFCH while distilled water served as control. The test solution was replaced every $24 \mathrm{~h}$ with fresh solutions until the roots were fully developed. The best developed 10 roots of each onion in each group were collected, measured with a ruler and the mean root length was calculated. The percentage growth inhibition was calculated using the expression:

$$
\text { Percentage Inhibition }=\left(\frac{\text { Root length }_{\text {control }}-\text { Root length }_{\text {sample }}}{\text { Root length }_{\text {control }}} \times 100\right)
$$

\section{Preparation of Onion Roots Homogenates:}

The (Allium cepa) Onions roots $(0.5 \mathrm{~g})$ were homogenized with $5 \mathrm{ml}(0.85 \% \mathrm{v} / \mathrm{v})$ normal saline with mortar and pestle. The homogenates were centrifuged at $3000 \mathrm{rpm}$ for 15 minas described earlier. The supernatants were collected, stored and the residues were washed with $0.1 \mathrm{M} \mathrm{NaOH}$ and further centrifuged at $3000 \mathrm{rpm}$ for $15 \mathrm{~min}$. The supernatants were combined and used for the estimation of total protein.

\section{Estimation of Total Protein Concentrations:}

The protein concentrations in the (Allium cepa) Onions roots homogenates were estimated as described by Schacterle and Pollack (1973), using bovine serum albumin as standard. The onions roots homogenates $(1 \mathrm{ml})$ were pipetted into different clean dried test tubes. One (1ml) Alkaline Copper reagent (10\% (w/v) $\mathrm{Na}_{2} \mathrm{CO}_{3}, 0.1 \%$ (w/v) K-Na-tartrate and $0.05 \% \mathrm{CuSO}_{4} .5 \mathrm{H}_{2} \mathrm{O}$ in $0.1 \mathrm{M} \mathrm{NaOH}$ ) was added and mixed thoroughly. The mixture was left to stand for $10 \mathrm{~min}$ at room temperature undisturbed after which $2 \mathrm{ml}$ of FolinCiocalteu's Phenol reagent (1:10 dilution) was added carefully. It was then incubated at 55 ${ }^{\circ} \mathrm{C}$ for $15 \mathrm{~min}$ in a water bath, tubes were collected and allowed to cool. The blank was treated similarly with distilled water in place of the sample. The absorbance was read at 650 $\mathrm{nm}$ against the blank. A standard calibration curve was prepared using bovine albumin 0.0, $40,80,120,160$ and $200 \mu \mathrm{g} / \mathrm{ml}$. The protein concentrations were extrapolated from the standard calibration curve and expressed as $\mathrm{mg} / \mathrm{g}$ fresh weigh of plant sample $(\mathrm{mg} / \mathrm{g}$ AFCHE).

\section{Cytotoxic Test - Brine Shrimp Lethality Bioassay:}

The cytotoxicity activity of AFCHE was carried out according to the method of Chatterjee et al. (2013). Typically, $1 \mathrm{~g}$ of Artemia salina (Linn) cysts were aerated in a 400 $\mathrm{ml}$ capacity specially constructed container containing $300 \mathrm{ml}$ filtered seawater $(\mathrm{pH} 8.2)$ collected from the Atlantic Ocean (Bar Beach), Ikoyi, Lagos, Nigeria. After 48 hr incubation 
at room temperature, under continuous illumination of fluorescent lamp, newly hatched freeswimming (pink-coloured) nauplii were harvested.

The assay system contained varying concentrations of $\operatorname{AFCHE~}(0,20,4060,80$, and $100 \mu \mathrm{g} / \mathrm{ml}$ ) and control in sterilised transparent plastic containers. To each container was transferred 20 nauplii and incubated for $24 \mathrm{hr}$, under constant illumination with a fluorescent lamp. The number of survived nauplii was counted with a hand lens at $3 \mathrm{hr}$ intervals. Replicates (5) were prepared for each concentration of AFCHE. Then, percentage mortality was estimated after $12 \mathrm{hr}$ as:

Percentage mortality $=\frac{\text { Number of survived nauplii after } 24 \mathrm{hr}}{\text { Number of nauplii at the start of the experiement }} \times 100$

The effectiveness or the concentration-mortality relationship of AFCHE was expressed as a median lethal concentration $\left(\mathrm{LC}_{50}\right)$ value.

\section{RESULTS}

\section{GC-MS Profile of AFCHE:}

The spectrum of AFCHE as revealed by GC-MS analysis is shown in Figure 1. More than a hundred phytoconstituents were detected and the reported biological activities of some of the phytoconstituents are anti-inflammation, antioxidant, cytotoxic, anti-cancer, anti-fungal, bactericidal, antiviral, antileishmanial, wound healing, hypotensive, etc. The most abundant constituents in AFCHE include chalcones ( $\sim 3 \%)$, vitamin $\mathrm{E}(\sim 5 \%)$, glycerine $(\sim 4 \%)$, octadecanoic acid $(\sim 7 \%)$, oleic acid ( $\sim 7 \%)$, linoleic acid ethyl ester ( $\sim 9 \%)$, sterols (campesterol, stigmasterol and lupeol, sitosterol $\sim 10 \%$ ).

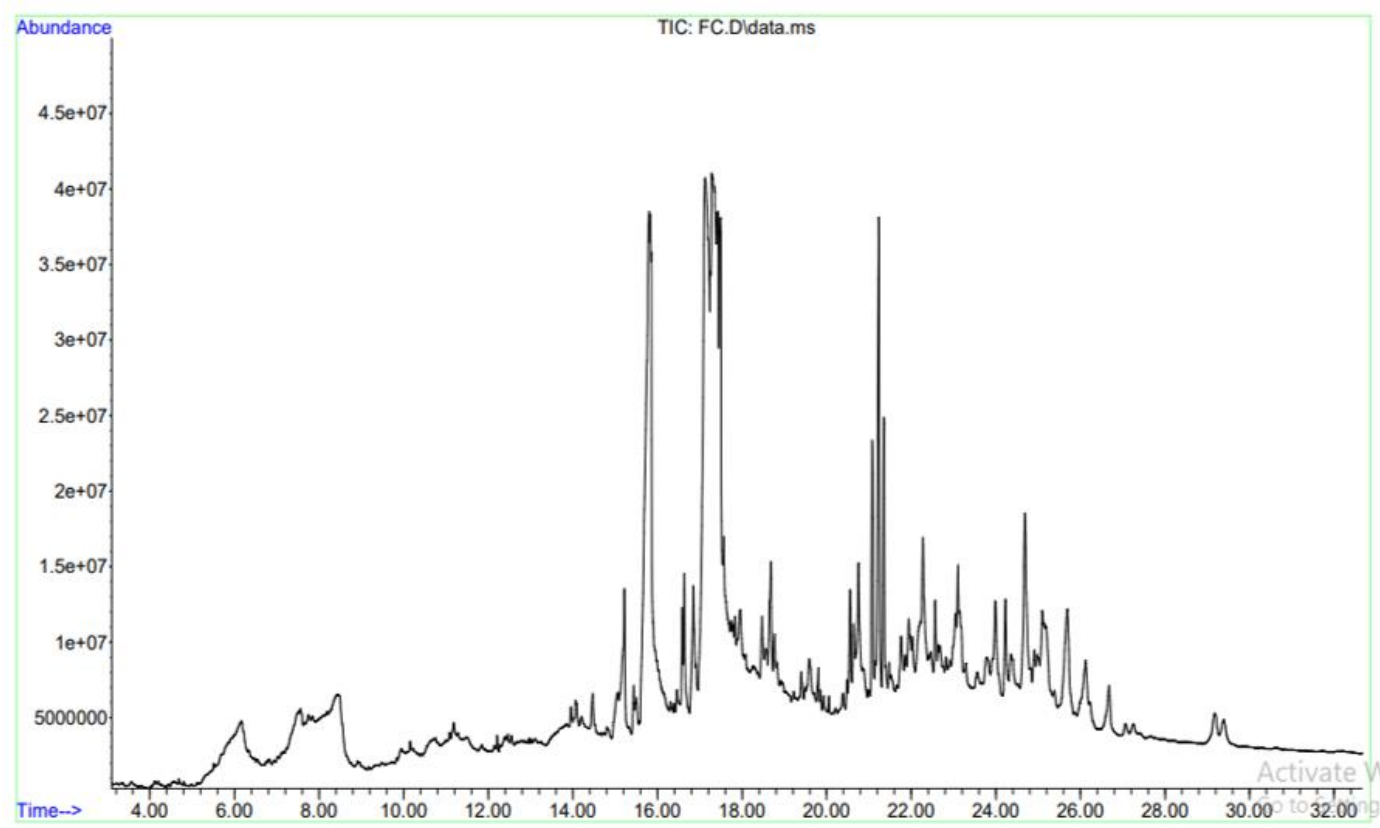

Fig. 1: GC-MS Spectrum of AFCHE

\section{Allium cepa Test:}

From the Allium cepa test, there was observed significant decrease in the root length of the onion bulb with an increase in the concentration of AFCHE (Fig. 2). The percentage inhibition of the root growth also increased as the concentration of AFCHE increased (Fig. 3 ) and the $\mathrm{IC}_{50}$ was $97.745 \pm 3.76 \mu \mathrm{g} / \mathrm{ml}$. There was a significant decrease in the concentration of protein in the root with an increase in AFCHE concentration (Fig. 4). 


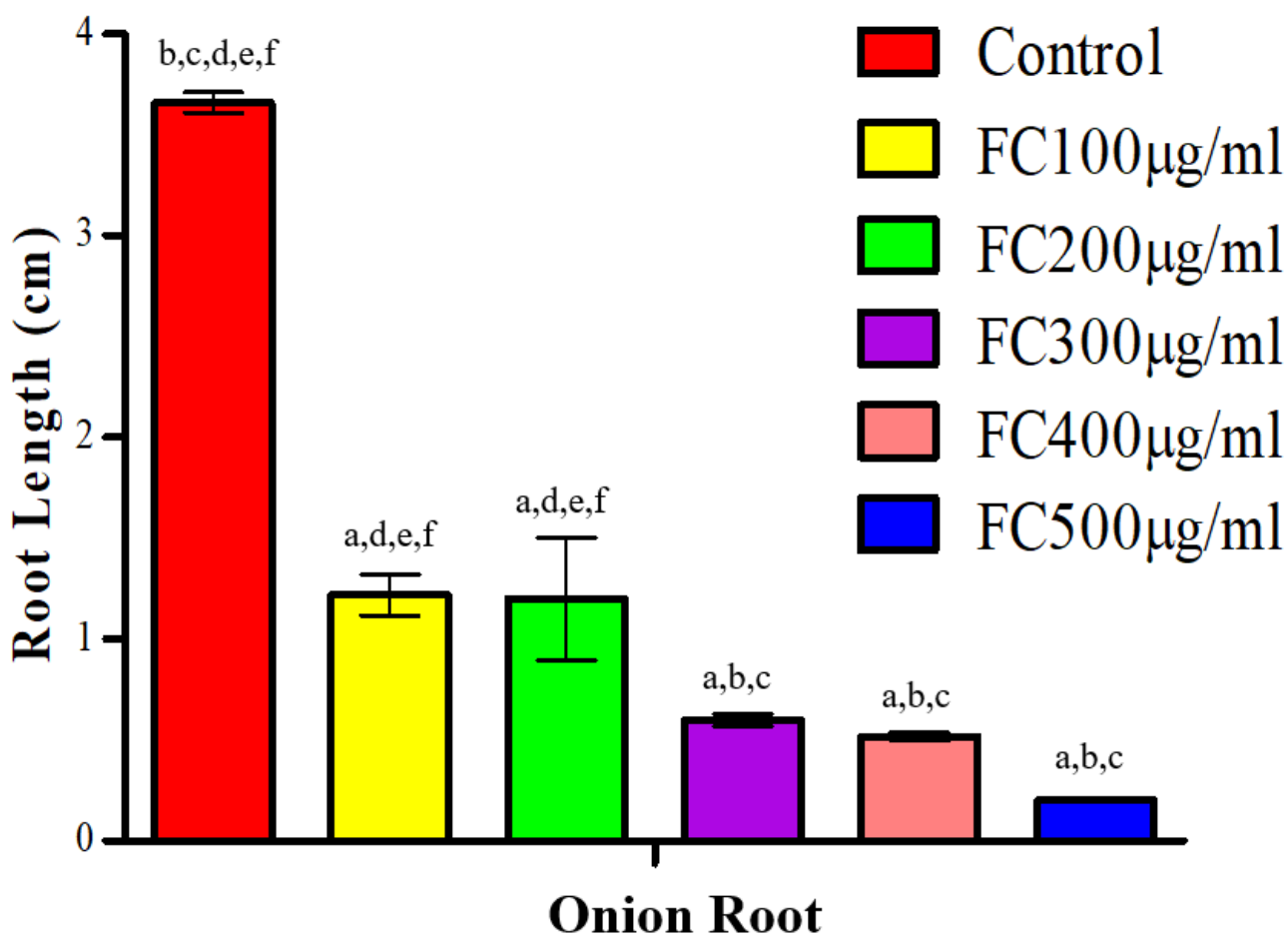

Fig. 2: Onion Root Length

Each value represented Mean \pm SEM of $n=5$. The values with alphabetic superscripts are statistically significant at $\mathrm{P}<0.05$. a compares Control with others, b compares AFCHE $100 \mu \mathrm{g} / \mathrm{ml}$ with others, c compares AFCHE $200 \mu \mathrm{g} / \mathrm{ml}$ with others, d compares AFCHE $300 \mu \mathrm{g} / \mathrm{ml}$ with others, e compares AFCHE $400 \mu \mathrm{g} / \mathrm{ml}$ with others, f compares AFCHE $500 \mu \mathrm{g} / \mathrm{ml}$ with others.

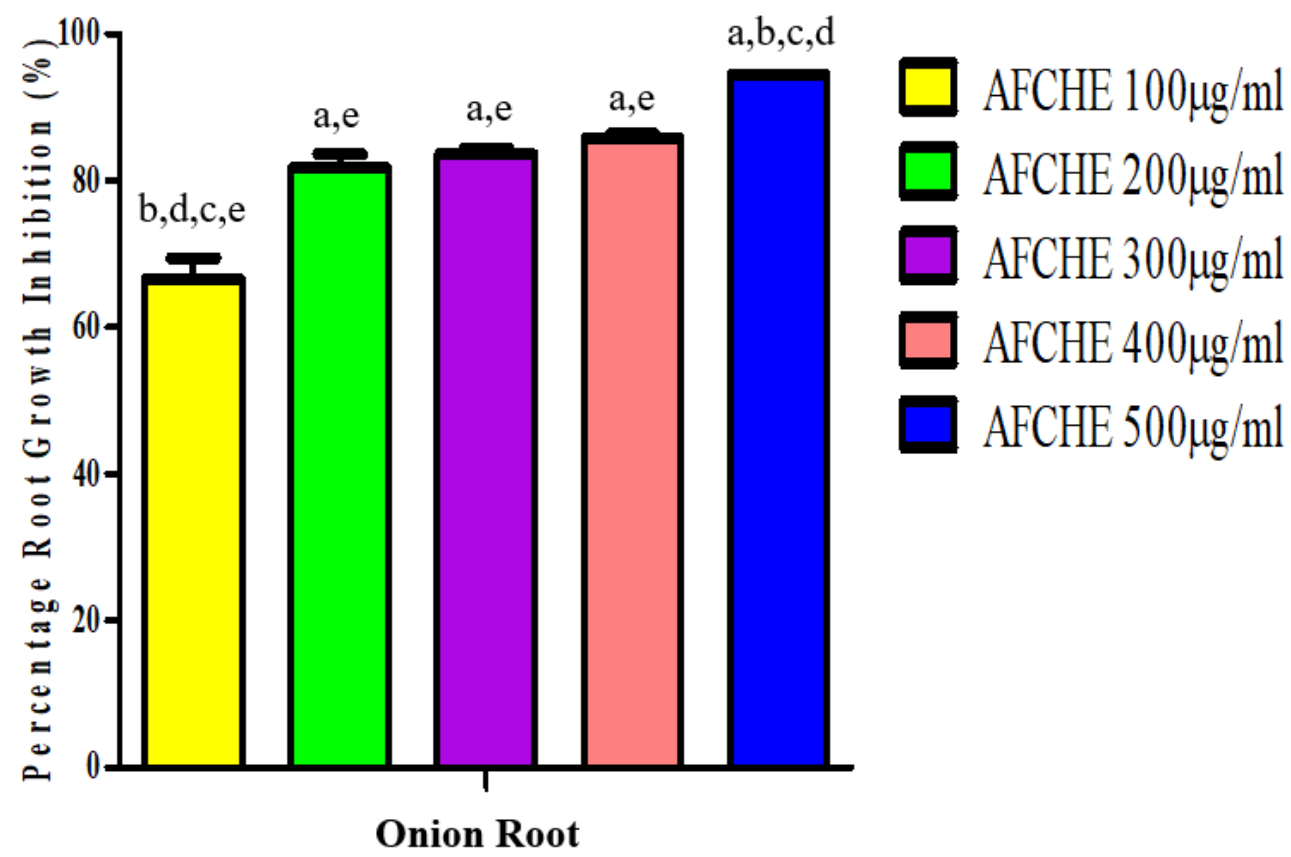

Fig. 3: Percentage Onion Root Growth Inhibition

Each value represented Mean \pm SEM of $n=5$. The values with alphabetic superscripts are statistically significant at $\mathrm{P}<0.05$. a compares AFCHE $100 \mu \mathrm{g} / \mathrm{ml}$ with others, b compares AFCHE $200 \mu \mathrm{g} / \mathrm{ml}$ with others, c compares AFCHE $300 \mu \mathrm{g} / \mathrm{ml}$ with others, d compares AFCHE $400 \mu \mathrm{g} / \mathrm{ml}$ with others, e compares AFCHE $500 \mu \mathrm{g} / \mathrm{ml}$ with others. 


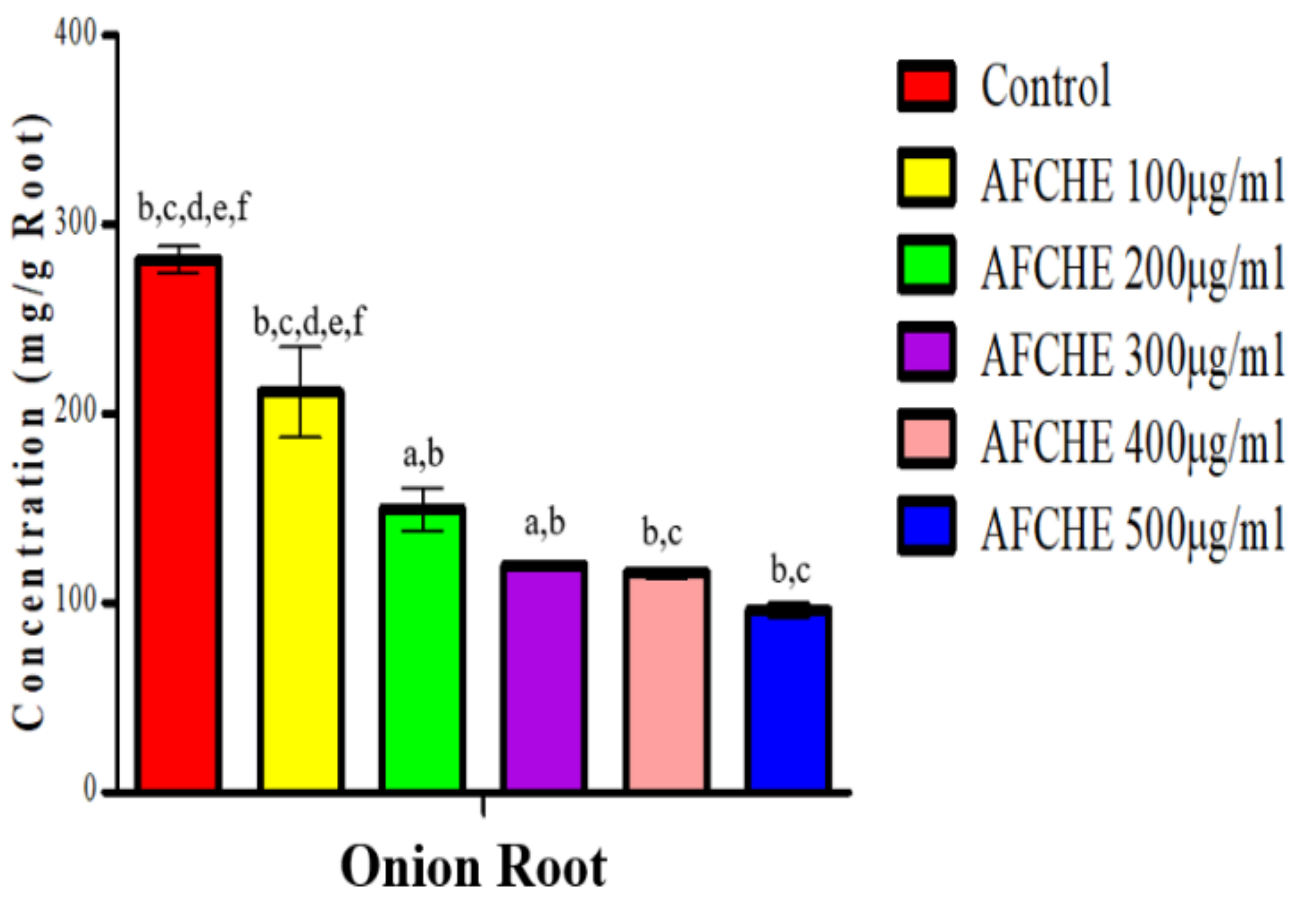

Fig. 4: Protein Concentration in Onion Root

Each value represented Mean \pm SEM of $n=5$. The values with alphabetic superscripts are statistically significant at $\mathrm{P}<0.05$. a compares Control with others, b compares AFCHE $100 \mu \mathrm{g} / \mathrm{ml}$ with others, c compares AFCHE $200 \mu \mathrm{g} / \mathrm{ml}$ with others, d compares AFCHE $300 \mu \mathrm{g} / \mathrm{ml}$ with others, e compares AFCHE $400 \mu \mathrm{g} / \mathrm{ml}$ with others, f compares AFCHE $500 \mu \mathrm{g} / \mathrm{ml}$ with others.

\section{Brine Shrimp Lethality Bioassay:}

As the time progressed at $3 \mathrm{hr}$ intervals, the nauplii died at a logarithmic rate from the highest concentration of the extract to the lowest (i.e. from $100 \mu \mathrm{g} / \mathrm{ml}-20 \mu \mathrm{g} / \mathrm{ml}$ ) except control group of the experiment (Table 1). The experiment was stopped after $12 \mathrm{hr}$ against $24 \mathrm{hr}$ it was designed for because all the nauplii in the test had died as at $12 \mathrm{hr}$.

There was an increase in percentage mortality of the nauplii with an increase in the concentration of AFCHE (Table 2). The observed $\mathrm{LC}_{50}$ value was as low as $25.939 \pm 1.32$ $\mu \mathrm{g} / \mathrm{ml}$ and portrayed the extract as highly toxic.

Table 1: Brine Shrimp Lethality

\begin{tabular}{|l|l|l|l|l|l|}
\hline $\begin{array}{c}\text { USCP } \\
(\boldsymbol{\mu g} / \mathbf{m l})\end{array}$ & $\begin{array}{c}\text { Naupli No } \\
\mathbf{0 h r}\end{array}$ & $\begin{array}{c}\text { Naupli No } \\
\mathbf{3 h r}\end{array}$ & $\begin{array}{c}\text { Naupli No } \\
\mathbf{6 h r}\end{array}$ & $\begin{array}{c}\text { Naupli No } \\
\mathbf{9 h r}\end{array}$ & $\begin{array}{c}\text { Naupli No } \\
\mathbf{1 2 h r}\end{array}$ \\
\hline Control $(\mathbf{0})$ & $20.00 \pm 0.00$ & $20.00 \pm 0.00$ & $19.60 \pm 0.25$ & $18.25 \pm 0.25$ & $17.75 \pm 0.29$ \\
\hline $\mathbf{2 0}$ & $20.00 \pm 0.00$ & $8.20 \pm 0.97$ & $6.33 \pm 0.33$ & $1.50 \pm 0.50$ & $0.00 \pm 0.00$ \\
\hline $\mathbf{4 0}$ & $20.00 \pm 0.00$ & $8.20 \pm 0.97$ & $4.50 \pm 0.50$ & $1.50 \pm 0.50$ & $1.00 \pm 0.00$ \\
\hline $\mathbf{6 0}$ & $20.00 \pm 0.00$ & $7.50 \pm 0.98$ & $3.00 \pm 1.00$ & $1.00 \pm 0.00$ & $0.00 \pm 0.00$ \\
\hline $\mathbf{8 0}$ & $20.00 \pm 0.00$ & $6.60 \pm 0.40$ & $2.50 \pm 0.50$ & $1.33 \pm 0.33$ & $0.00 \pm 0.00$ \\
\hline $\mathbf{1 0 0}$ & $20.00 \pm 0.00$ & $3.60 \pm 0.40$ & $0.75 \pm 0.25$ & $0.00 \pm 0.00$ & $0.00 \pm 0.00$ \\
\hline
\end{tabular}

Each value represented Mean \pm SEM of $n=5$ replicates. 
Table 2: Percentage Mortality of Nauplii

\begin{tabular}{|l|c|}
\hline Concentration $(\mu \mathrm{g} / \mathrm{ml})$ & Percentage Mortality \\
\hline 20 & $67.700 \pm 1.00$ \\
\hline 40 & $77.041 \pm 1.70$ \\
\hline 60 & $84.694 \pm 2.62$ \\
\hline 80 & $87.245 \pm 4.48$ \\
\hline 100 & $96.173 \pm 1.44$ \\
\hline $\mathrm{LC}_{50}(\mu \mathrm{g} / \mathrm{ml})$ & $25.939 \pm 1.32$ \\
\hline
\end{tabular}

Each value represented Mean \pm SEM of $n=5$ replicates.

The control group change rate $(\%)$ was taken as $100 \%$, and the other concentrations were compared to this group.

$\%$ Inhibition $=\left(\frac{\text { Naupli number control }- \text { Naupli number }}{\text { Nample }} \times 100\right)$

\section{DISCUSSION}

The use of medicinal plants as an approach in the prevention and treatment of cancer has been followed for many years and many therapeutic plants with anticancer activity are reported in the literature (Hekin et al., 2018). As the interest in organic and simple lifestyles grows, the interest in plant-based medicine also increases (Schultz et al., 2020). In addition, adverse effects and drug interactions are major restrictions in synthetic anticancer drugs; therefore, plants have been investigated across the world to exploit novel and potential sources of anticancer agents (Ntungwe et al., 2020).

The use of parameters related to Allium cepa root growth to assess the toxicity of several substances has been increasing, because data about Allium cepa can provide information about lethal effects of the compounds, and delay in root growth can provide information about sub-lethal effects (Pantano et al., 2021). With root growth data of all treatments and negative control of a bioassay, the concentration at which 50\% inhibition of root growth occurs when compared with negative control $\left(\mathrm{IC}_{50}\right)$ can be estimated.

There was a significant reduction in the root lengths of onion bulbs exposed to different concentrations of AFCHE in a dose-dependent manner. The root growth inhibition could have occurred as a result of the inhibition of cell division and it is thus an index for estimating general toxicity. It occurs when roots are exposed to extreme $\mathrm{pH}$, or to substances that prevent nutrient uptake (Owolarafe et al., 2020). The inhibitory effects could also be due to cell extension, that is, cessation of root elongation which is correlated with the decrease in protein concentration observed. Metal stress can act at different sites to inhibit a large number of enzymes having functional sulfhydryl groups. It results in a deleterious effect in the normal protein form by disrupting the pathways and protein synthesis (Chen et al., 2021). This implies that the hydroalcoholic extract was toxic to the onion bulbs and inhibited the growth of the onion root as the concentration increased.

Brine shrimp lethality bioassay is an efficient, rapid and inexpensive assay for testing the bioactivity of plant extracts. It is an excellent choice for elementary toxicity investigations based on the ability to kill laboratory-cultured Artemia nauplii (Sharma et al., 2013; Naidu et al., 2014). Studies have demonstrated a positive correlation between the brine shrimp lethality and oral lethality test in mice in medicinal plant research.

Brine shrimp lethality assay after $12 \mathrm{hr}$ of exposure to the hydroalcoholic extract of Annona squamosa L. and positive control were investigated. As the time progresses at each $3 \mathrm{hr}$ interval, the number of nauplii decreased at a logarithmic rate from the highest concentration of the extract to the lowest (i.e. from $100 \mu \mathrm{g} / \mathrm{ml}-20 \mu \mathrm{g} / \mathrm{ml}$ ) except control group of the experiment

In the present study, different measures of lethality were observed with exposure to different concentrations of FACHE (20, 40 60, 80, and $100 \mu \mathrm{g} / \mathrm{ml})$ and control. According 
to Meyer's toxicity index, hydroalcoholic extracts with $\mathrm{LC}_{50}<1000 \mu \mathrm{g} / \mathrm{ml}$ are considered as toxic, while extracts with $\mathrm{LC}_{50}>1000 \mu \mathrm{g} / \mathrm{ml}$ are considered non-toxic (Meyer et al., 1982; Rahman et al., 2020). Clarkson's toxicity criterion for the toxicity assessment of plant extracts classifies extracts in the following order: extracts with $\mathrm{LC}_{50}$ above $1000 \mu \mathrm{g} / \mathrm{ml}$ are non-toxic, $\mathrm{LC}_{50}$ of $500-1000 \mu \mathrm{g} / \mathrm{ml}$ are low toxic, extracts with $\mathrm{LC}_{50}$ of $100-500 \mu \mathrm{g} / \mathrm{ml}$ are medium toxic, while extracts with $\mathrm{LC}_{50}$ of $0-100 \mu \mathrm{g} / \mathrm{ml}$ are highly toxic (Clarkson et al., 2004; Asghar et al., 2020). From the results obtained, $\mathrm{LC}_{50}$ value of $25.939 \mu \mathrm{g} / \mathrm{ml}$ of AFCHE qualified it as a highly toxic substance according to the toxicity indices by Meyer and Clarkson, and it is a highly recommended anti-cancer agent worth screening.

Many of the phytoconstituents detected in GC-MS analysis have proven biological activities many of which are responsible for the cytotoxic activities observed in this study and also presented AFCHE as a good lead in search of anticancer drugs. For example, chalcones (Chavan et al., 2016), hexadecanoic acid (Nagata et al., 2015), squalene (Kelly, 1999; Minhas et al., 2020), plant sterols such as campesterol, stigmasterol and lupeol have also proven to exhibit anti-tumour properties (Luo et al., 2015).

Conclusively, the anticancer activities of AFCHE should be evaluated on cancer cell lines for their potential as an anti-cancer agent.

Declaration of interest: None

\section{REFERENCES}

Akther, T.; Khan, M. S. and Hemalatha, S. (2017). Extraction of flavonoids from various parts of Couroupita guianensis and its efficacy against pathogenic bacteria. Asian Journal of Pharmaceutical and Clinical Research, 10(4):354

Asghar, M. A.; Yousuf, R. I.; Shoaib, M. H. and Asghar, M. A. (2020). Antibacterial, anticoagulant and cytotoxic evaluation of biocompatible nanocomposite of chitosan loaded green synthesized bioinspired silver nanoparticles. International Journal of Biological Macromolecules, 160: 934-943.

Azad, A.K.; Azizi, W. S.; Ismail, A. F. H.; Abbas, S. A.; Uddin, J. and Labu, Z. K. (2019). Phytochemical and toxicity evaluation of traditional herb: Lagerstroemia speciosa L. (Banaba) by MCF-7 cell line and brine shrimp lethality bioassay. Bangladesh Pharmaceutical Journal, 22(1): 45-49.

Chatterjee, P. and Ghosh, A. (2013). Brine shrimp cytotoxic activity of 50\% alcoholic extract of Croton Bonplandianum Baill. Asian Journal of Pharmaceutical and Clinical Research, 6(3): 40-41.

Chavan, B. B.; Gadekar, A. S.; Mehta, P. P.; Vawhal, P. K.; Kolsure, A. K. and Chabukswar, A. R. (2016). Synthesis and medicinal significance of chalcones-A review. Asian Journal of Biomedical and Pharmaceutical Sciences, 6(56): 01-07

Chen, Q. Y.; Liu, L.; Yang, L.; Dong, B.; Wen, Y.; Zhang, Q. and Cao, D. (2021). Response of sulfhydryl compounds in subcells of Cladophora rupestris under $\mathrm{Pb}$ stress. Environmental Science and Pollution Research, 28: 13112-13123.

Clarkson, C.; Maharaj, V. J.; Crouch, N. R.; Grace, O. M.; Pillay, P.; Matsabisa, M. G.; Bhagwandin, N.; Smith, P. J. and Folb, P. I. (2004). In vitro antiplasmodial activity of medicinal plants native to or naturalized in South Africa. Journal of Ethnopharmamacy, 92: 177-191.

Dare, C. A.; Onwumelu, R. N. and Oyedapo, O. O. (2013). Biochemical Studies on the Effects of Polyphenols from Fermented and Unfermented Acetone Extracts of Cocoa (Theobroma cacao L.) Seeds on Antioxidant Enzymes of StreptozotocinInduced Diabetic Rats. Nigerian Journal of Biochemistry and Molecular Biology, 28(1\&2): 44-58. 
Dutta S., Mahalanobish, S.; Saha, S.; Ghosh, S. and Sil, P. C. (2019). Natural products: An upcoming therapeutic approach to cancer. Food and Chemical Toxicology, 128: 240-255

Dutta, J.; Ahmad, A. and Singh, J. (2018). Study of industrial effluents induced genotoxicity on Allium cepa. Caryologia, 71(2): 139-145

Henkin, J.M.; Ren, Y.; Soejarto, D. D. and Kinghorn, A.D. (2018). The search for anticancer agents from tropical plants. Progress in the Chemistry of Organic Natural Products, 107: 1-94

Kelly, G. S. (1999). Squalene and its potential clinical uses. Alternative Medicine Review: A Journal of Clinical Therapeutic, 4(1): 29-36

Luo, X.; Su, P. and Zhang, W. (2015). Advances in microalgae-derived phytosterols for functional food and pharmaceutical applications. Marine Drugs, 13: 4231-4254.

Meyer, B. N.; Ferrigni, N. R.; Putnam, J. E.; Jacobsen, L. B.; Nichols, D. E. and McLaughlin, J. L. (1982). Brine Shrimp: A convenient general bioassay for active plant constituents. Planta Medica, 45: 31-34.

Minhas, V.; Kumar, R.; Moitra, T.; Singh, R.; Panda, A.K. and Gupta, S. K. (2020). Immunogenicity and contraceptive efficacy of recombinant fusion protein encompassing Sp17 spermatozoa-specific protein and GnRH: Relevance of adjuvants and microparticles based delivery to minimize number of injections. American Journal of Reproductive Immunology, 3(4): e13218

Nagata, Y.; Ishizaki, I.; Waki, M.; Ide, Y.; Hossen, M. A.; Ohnishi, K.; Miyayama, T.; Setou, M. (2015). Palmitic acid, verified by lipid profiling using secondary ion mass spectrometry, demonstrates anti-multiple myeloma activity. Leukemia Research, 39(6): 638-645

Naidu, J. R.; Ismail, R. and Sasidharan, S. (2014). Acute oral toxicity and brine shrimp lethality of methanol extract of Mentha spicata L. (Lamiaceae). Tropical Journal of Pharmaceutical Research, 13(1): 101-107

Ntungwe, N.; Domínguez-Martín, E. M.; Roberto, A.; Tavares, J.; Isca, V.; Pereira, P.; Cebola, M. and Rijo, P. (2020). Artemia species: An important tool to screen general toxicity samples. Current Pharmaceutical Design, 26(24): 2892-2908

Owolarafe, T. A.; Salawu, K.; Ihegboro, G. O.; Ononamadu, C. J.; Alhassan, A. J. and Wudil, A. M. (2020). Investigation of cytotoxicity potential of different extracts of Ziziphus mauritiana (Lam) leaf Allium cepa model. Toxicology Reports, 7: 816-821.

Pantano, G.; Mazzeo, D.E.C.; Rocha, T. H. S.; Marin-Morales, M. A.; Fadini, P. S. and Mozeto, A. A. (2021). Toxicity of the sawdust used for phosphorus recovery in a eutrophic reservoir: experiments with Lactuca sativa and Allium cepa. Environmental Science and Pollution Research, 28(14): 18276-18283

Pesnya, D. S.; Romanovsky, A. V.; Serov, D. A. and Poddubnaya, N. Y. (2017). Genotoxic effects of Heracleum sosnowskyi in the Allium cepa test. Caryologia, 70(1): 55-61

Rahman, J.; Tareq, A. M.; Hossain, M. M.; Sakib, S. A.; Islam, M. N.; Ali, M. H.; Uddin, A. B.; Hoque, M.; Nasrin, M. S.; Emran, T. B.; Capasso, R.; Reza, A. S. and SimalGandara, J. (2020). Biological evaluation, DFT calculations and molecular docking studies on the antidepressant and cytotoxicity activities of Cycas pectinata Buch.Ham. compounds. Pharmaceuticals, 13: 232.

Ranjan, A.; Ramachandran, S.; Gupta, N.; Kaushik, I.; Wright, S.; Srivastava, S.; Das, H.; Srivastava, S.; Prasad, S.; Srivastava, S. K. (2019). Role of Phytochemicals in Cancer Prevention. International Journal of Molecular Sciences, 20(20): 4981.

Schacterle, G. R. and Pollack, R. L. (1973). A simplified method for the quatitative assay of small amounts of protein in biologic material. Analytical Biochemistry, 51(2): 654655 
Schultz, F.; Anywar, G.; Wack, B.; Quave, C. L. and Garbe, L. (2020). Ethnobotanical study of selected medicinal plants traditionally used in the rural Greater Mpigi region of Uganda. Journal of Ethnopharmacology, 256: 112742

Sharma, N.; Gupta, P. C.; Singh, A. and Rao, C. V. (2013). Brine shrimp bioassay of Pentapetes phoenicea Linn. and Ipomoea carnea jacq. Leaves. Der Pharmacia Lettre, 5(1): 162-167

Sharma, S. and Vig, A. P. (2012). Genotoxicity of atrazine, avenoxan, diuron and quizalofop-p-ethyl herbicides using the Allium cepa root chromosomal Aberration assay. Terrestrial and Aquatic Environmental Toxicology, 6(2): 90-95.

Sultana, S.; Munir, N.; Mahmood, Z.; Riaz, M.; Akram, M.; Rebezov, M.; Kuderinova, N.; Moldabayeva, Z.; Shariati, M. A.; Rauf, A. and Rengasamy, K. R. R. (2021). Molecular targets for the management of cancer using Curcuma longa Linn. phytoconstituents: A Review. Biomedicine \& Pharmacotherapy, 135: 111078

Yavuz, K. A. and Kilic, E. (2017). Evaluation of the genotoxicity of commercial formulations of ethephon and ethephon+cyclanilide on Allium cepa L. root meristematic cells. Caryologia, 70: 3229-3237

Yekeen, T. A.; Azeez, M. A.; Lateef, A.; Asafa, T. B.; Oladipo, C. I.; Badmus, A. J.; Adejumo, A. S. and Ajibola, A. A. (2017). Cytogenotoxicity potentials of cocoa pod and bean-mediated green synthesized silver nanoparticles on Allium cepa cells. Caryologia, 70(4): 366-377.

Zotina, T.; Medvedeva, M.; Trofimova, E.; Alexandrova, Y.; Dementyev, D. and Bolsunovsky, A. (2015). Chromosomal abnormalities in roots of aquatic plant Elodea Canadensis as a tool for testing genotoxicity of bottom sediments. Ecotoxicology and Environmental Safety, 122: 384-391 